\title{
Gender differences in health-related quality of life of patients with active epilepsy and clinical factors that are signs of their associations: a retrospective cross-sectional study
}

Aktif epilepsi hastalarında sağlıkla ilişkili yaşam kalitesinin cinsiyetler arası farklılıkları ve klinik faktörler ile ilişkisinin belirleyicileri: Retrospektif kesitsel bir çalışma

iD Sehnaz Basaran ${ }^{\mathbf{a}}$

Department of Neurology, Kocaeli Derince Health Research Center, University of Health Sciences, Kocaeli, Turkey

\begin{abstract}
Introduction: Improving the health-related quality of life of patients with epilepsy has a prominent role in the management of sickness. In this study, we aim to compare health-related life quality (QOL) between male and female active epilepsy patients and investigate the clinical factors that may impair their quality of life.

Methods: Total 172 patients (82 female, 90 male) which are traced about their diagnosis of active epilepsy are included in this study. All of the subscales related to the Quality of Life in Epilepsy Inventory (QOLIE-31), Beck Depression Inventory (BDI) and Beck Anxiety Inventory (BAI) are compared between the female and male patients with epilepsy. In addition, the clinical factors associated with the illness and the topics about whether there are relations between quality of life (QOL) and psychiatric symptoms or not are evaluated separately for both genders.

Results: It is examined that there is a considerably decrease in the subscales of female with epilepsy related to the overall $(p=0.054)$, social $(p=$ $0.041)$ and cognitive functions $(\mathrm{p}=0.043)$ of the QOLIE-31 test compared to male with epilepsy. It is determined in the correlation analysis of male patients that all of the QOLIE-31 subscales are negatively correlated with seizure frequency. Negatively correlation with seizure frequency is examined in all of the categories except for the subscales related to the emotional well-being and medication effects. Additionally, it is confirmed that there is a significant correlation between BDI and BAI scores and seizure frequency in both groups.

Conclusion: These results suggest that the rise in epileptic seizure frequency may affect women's social and cognitive skills in the course of the disease. Moreover, it is seen that the rise in epileptic seizure frequency is the most important clinical factor associated with the decline in QOL of people with epilepsy. Hence, gender-focused studies and clinical approaches may cause the improvement in the treatment modalities and QOL in epilepsy.
\end{abstract}

Keywords: Epilepsy, Gender, Active Epilepsy, Health-related Quality of Life

\section{$\ddot{O} \mathbf{z}$}

Giriş: P Epilepsi hastalarında sağlıkla ilişkili yaşam kalitesinin düzeltilmesi hastalığın yönetiminde oldukça önemli bir role sahiptir. Biz bu çalışmada, aktif epilepsisi olan kadın ve erkek bireylerde sağlikla ilişkili yaşam kalitesini karşılaştırmayı ve yaşam kalitesini bozabilecek klinik faktörleri değerlendirmeyi amaçladık.

Yöntem: Bu çalışmaya aktif epilepsi tanısı ile takip edilen toplam 172 hasta (82 kadın, 90 erkek) dahil edildi. Epilepside Yaşam Kalitesi Ölçeği31 (QOLIE-31), Beck Depresyon ölçeği (BDI), ve Beck Anksiyete ölçeğine (BAI) ait tüm skorlar kadın ve erkek epilepsi hastaları arasında karşılaştırıldı. Buna ek olarak, hastalığa ilişkin faktörler, yaşam kalitesi ve psikiyatrik semptomlar arasında ilişki olup olmadığ her iki cinsiyet için ayrı ayrı değerlendirildi.

Bulgular: Epilepsisi olan kadınlarda QOLIE-31 testinin total $(\mathrm{p}=0,054)$, sosyal $(\mathrm{p}=0,041)$ ve kognitif fonksiyonlara $(\mathrm{p}=0,043)$ ait skorlarında erkek hastalara göre anlamlı düzeyde düşüklük olduğu izlendi. Epilepsili erkek hastaların korelasyon analizinde QOLIE-31 testinin tüm skorlarının nöbet sıklığı ile negatif yönde korele olduğu saptandı. Kadın epilepsi hastalarında ise emosyonel iyilik ve ilaç etkilerine ait skorlar haricindeki tüm kategorilerde nöbet sıklığı ile negatif yönde korelasyon izlendi. Ayrıca her iki grupta depresyon ve anksiyete semptomları ile artmış ile nöbet sıklı̆̆ı arasında anlamlı ilișki olduğu tespit edildi.

Sonuç: Bu bulgular epileptik nöbet sıklığındaki artışın kadın epilepsili hastaların sosyal ve kognitif yetilerini etkileyebileceğini göstermektedir. Ayrıca, artmış nöbet sıklığının, epilepsili bireylerin yaşam kalitesinde düşüş ile ilişkili en önemli klinik değişken olduğu izlenmiştir. Bu nedenle epilepsi hastalarında cinsiyet farklılıklarını değerlendiren çalışma ve klinik yaklaşımlar, tedavi modalitelerinde ve hastaların yaşam kalitesinde düzelmeye neden olabilir.

Anahtar kelimeler: epilepsi, cinsiyet, aktif epilepsi, sağlıkla ilişkili yaşam kalitesi

\begin{tabular}{|c|c|c|c|c|}
\hline Received & Accepted & Published Online & Corresponding Author & E-mail \\
\hline November 26, 2021 & January 24, 2022 & March 17, 2022 & Sehnaz Basaran, M.D. & $\underline{\text { basaransehnaz@yahoo.com }}$ \\
\hline Correspondence & $\begin{array}{l}\text { Dr. Şehnaz Başaran. İbni Sina Mah, Lojman Sok. Derince Eğitim ve Araştırma Hastanesi, Nöroloji Anabilim Dalı, } \\
\text { 41900, İzmit/ Kocaeli-Turkey }\end{array}$ \\
\hline doi & https://doi.org/10.22391/fppc.1028627 \\
\hline
\end{tabular}


1. Epileptic seizures may affect women's social and cognitive skills in the course of the disease.

2. Seizure frequency is the most important disease-related factor associated with poorer health-related QOL.

\section{Introduction}

Epilepsy is the common neurological condition which occurs because of the recurrent unpredictable seizures [1]. These seizures include chronic and episodic patterns which can affect the health-related quality of life (QOL) in patients with epilepsy (PWE).

Active epilepsy can be defined as a disease period in which the seizures occur within the 5 years because of the regular treatment of antiepileptic drugs (AEDs) [2].

Previous studies have emphasized the fact that disease-related factors such as frequent and severe seizures, side effects of AEDs, comorbid psychiatric disorders, lower educational level and unemployment are associated with decreasing quality of life (QOL) [3]. Moreover, psychological consequences of the seizures regarding low self-esteem, social isolation, and stigmatization have a negative impact on well-being of patients in the daily life [4]. Nevertheless, the most relevant factor decreasing QOL in patients with epilepsy remains controversial. Several authors have suggested the impact of frequent seizures, whereas the others have reported the prominent effect of psychiatric comorbidities on poorer QOL in the course of the disease [5-6].

Although epilepsy has a remarkable impact on daily activities, factors that trigger QOL among men and women patients are not fully elucidated. Previous reports have reported no intersexuality while some studies have reported the determinants of QOL that may differ between male and female patients [7-8]. Therefore, the present study aims to determine intersexuality on QOL, and to identify whether the associated factors vary by gender in PWE or not.

\section{Methods \\ Study population}

This retrospective cross-sectional study was conducted at Epilepsy Outpatient Clinic from a tertiary care hospital between 2011 and 2021. According to the International League Against Epilepsy (ILAE) which was an official report in 2014; total 172 (82 women and 90 men) adult patients between the ages of 18-65 were diagnosed with active epilepsy. Sociodemographic and clinical data including age, gender, educational and employment status, duration of epilepsy, seizure type and frequency, AED usage were recorded from clinic files. In addition, QOLIE-31, Beck depression (BDI), and Beck Anxiety Inventories (BAI) were collected from the same files. Exclusion criteria were as follows. (1) patients who had active systemic disease, neurologic deficits, cognitive impairment, mental and/or psychiatric disorders, (2) concomitant psychogenic nonepileptic seizures, (3) prior epilepsy surgery and/or any neuromodulation therapy. (4) history of head trauma, stroke, and/or brain tumor.

\section{Ethical Approval, informed consent, and permissions}

The present study was approved by the Clinical Research Ethics Committee of X. (approval number: 2021-132).

\section{Inventories}

Quality of Life in Epilepsy Inventory-31 (QOLIE-31): This specific epilepsy inventory has been widely used for measuring QOL in PWE. The QOLIE-31 includes seven subscales and 31 items. These subscales are emotional well-being, social functioning, energy/fatigue, cognitive functioning, seizure worry, medication effects, and overall QOL. Each domain is calculated by measuring the mean score of the patients' responses within that subscale. A total score is measured by including indicated percentages of seven subscales, ranging from 1 to 100 and higher scores represent better QOL [10]. Also, Turkish validated version of the QOLIE-31 was performed by Mollaoglu et al. [11].

Beck Depression Inventory (BDI): This scale is a 21-item, Likert type, self-reported inventory generally used for evaluating the severity of depressive symptoms during the last two weeks of a patient. Each item ranges from 0 (no symptoms) to 3 (severe symptoms). The scores are ranging from 0 to 63 , scores $\geq 16$ points indicate depressive symptoms [12]. Also, Validity and reliability of the Turkish version were conducted by Hisli et al. [13].

Beck Anxiety Inventory (BAI): This self-reported scale consists of 21 multiple-choice questions evaluating the intensity of anxiety symptoms. Every question has four scales ranging from 0 (not at all) to 3 (severely). Total scores are classified as minimal ( $<7$ points), mild (8-15 points), moderate (16-25 points), and severe anxiety symptoms (26-63 points) [14]. Also, Turkish reliability and validity were reported by Ulusoy et al. [15].

\section{Statistical analysis}

The statistical package for social sciences (SPSS) 17.0 (SPSS Inc., Chicago, IL, USA) was used for the analysis. Quantitative data was presented with mean \pm standard deviation (SD), while qualitative data was summarized as numbers (n) and, percentages (\%). Intersexuality was evaluated by using the chi-square test for categorical, student t-test for continuous variables. Normality tests were performed for all variables. Independent sample t-test and Mann Whitney U test were used respectively to compare the differences between normally and non-normally distributed groups. Pearson and Spearman correlation analyses were carried out to explore the association between disease-related variables and the scores of the inventories among gender groups. All the tests were two-sided and a p-value of $<0.05$ was considered statistically significant. 


\section{Results}

\section{Sociodemographic and clinical features}

The clinical and demographic characteristics of male and female PWE were summarized in Table 1. Most features were similar among male and female group, except employment $(\mathrm{p}<0.001)$, marital status $(\mathrm{p}=0.004)$, and settlement $(\mathrm{p}=0.039)$.

Table 1. Sociodemographic and clinical features of patients with epilepsy

\begin{tabular}{|c|c|c|c|c|}
\hline & $\begin{array}{c}\text { Total } \\
(n=172)\end{array}$ & $\begin{array}{c}\text { Women } \\
(\mathrm{n}=82)\end{array}$ & $\begin{array}{c}\text { Men } \\
(n=90)\end{array}$ & $\mathbf{p}$ \\
\hline Age (years, mean, SD) & $36.25 \pm 12.43$ & $37.70 \pm 12.11$ & $35.00 \pm 12.76$ & 0.446 \\
\hline \multicolumn{5}{|l|}{ Gender $(\mathbf{n}, \%)$} \\
\hline Male & $90(52.3)$ & - & $90(100)$ & 0.542 \\
\hline Female & $82(47.7)$ & $82(100)$ & - & \\
\hline Education (years) & $8.78 \pm 3.50$ & $8.30 \pm 3.73$ & $9.22 \pm 3.23$ & 0.087 \\
\hline \multicolumn{5}{|l|}{ Employment (n, \%) } \\
\hline Unemployed & $72(41.8)$ & $62(36)$ & $10(5.8)$ & \\
\hline Employed & $95(55.2)$ & $19(11)$ & $76(44.2)$ & $<0.001$ \\
\hline Full time student & $2(1.2)$ & $1(0.6)$ & $1(0.6)$ & \\
\hline Retired & $3(1.7)$ & - & $3(1.7)$ & \\
\hline Socioeconomic status (low, n, \%) & $20(11.6)$ & $7(4)$ & $13(7.6)$ & 0.547 \\
\hline \multicolumn{5}{|l|}{ Marital Status (n, \%) } \\
\hline Single & $44(25.6)$ & $12(7)$ & $32(18.6)$ & \\
\hline Married & $125(72.7)$ & $69(40.1)$ & $56(32.6)$ & 0.004 \\
\hline Separated/Divorced & $3(1.7)$ & $1(0.6)$ & $2(1.2)$ & \\
\hline \multicolumn{5}{|l|}{ Settlement (n, \%) } \\
\hline City & $49(28.5)$ & $33(19.2)$ & $16(9.3)$ & \\
\hline Town & $115(67)$ & $62(36)$ & $53(30.8)$ & 0.039 \\
\hline Village & $8(4.7)$ & $4(2.3)$ & $4(2.3)$ & \\
\hline Age of disease onset (years) & $20.36 \pm 12.99$ & $19.87 \pm 12.82$ & $20.81 \pm 13.20$ & 0.637 \\
\hline Disease duration (years) & $16.61 \pm 12.12$ & $17.60 \pm 12.54$ & $15.70 \pm 11.71$ & 0.303 \\
\hline \multicolumn{5}{|l|}{ Seizure frequency } \\
\hline Last 3 months & $2.32 \pm 2.30$ & $1.97 \pm 2.52$ & $2.64 \pm 3.17$ & 0.208 \\
\hline Last 3 months & $6.54 \pm 6.48$ & $5.93 \pm 6.98$ & $7.10 \pm 9.06$ & 0.348 \\
\hline \multicolumn{5}{|l|}{ Last 1 year } \\
\hline \multicolumn{5}{|l|}{ Type of Epilepsy (n, \%) } \\
\hline Generalized & $46(26.7)$ & $23(13.4)$ & $23(13.4)$ & 0.680 \\
\hline Unclassified & $26(15.1)$ & $14(8.2)$ & $12(7)$ & \\
\hline \multicolumn{5}{|l|}{ Number of AEDs (n,\%) } \\
\hline None & $1(0.6)$ & $1(0.6)$ & $0(0)$ & \\
\hline $\begin{array}{l}\text { None } \\
\text { Monotherapy }\end{array}$ & $106(61.6)$ & $52(30.2)$ & $54(31.4)$ & 0.536 \\
\hline $\begin{array}{l}\text { Nionotherapy } \\
\text { Polytherapy }\end{array}$ & $65(37.8)$ & $29(16.9)$ & $36(20.9)$ & \\
\hline
\end{tabular}

AEDs: antiepileptic drugs, SD: standard deviation Student's t-test and chi-square tests were respectively used for continuous and categorical variables.

\section{Comparison of QOLIE-31 scores between male and female epileptic patients}

There were no statistical differences between QOLIE-31 subscale scores, except overall score (52.21 \pm 23.74 vs $45.76 \pm 19.37$, $\mathrm{p}=0.054)$, cognitive (male vs. female; $52.29 \pm 28.26$ vs $43.98 \pm 24.40, \mathrm{p}=0.041$ ), and social functions (male vs. female; $58.87 \pm 28.90$ vs $48.92 \pm 28.56, p=0.043$ ) among male and female epileptic patients. In addition, no significant differences were found in BDI and BAI scores between the groups. (Table 2)

Table 2. The scores of QOLIE-31, BDI, and BAI among patients with epilepsy

\begin{tabular}{rcccc}
\hline Questionnaires & $\begin{array}{c}\text { Total sample } \\
(\mathbf{n = 1 7 2})\end{array}$ & $\begin{array}{c}\text { Women } \\
(\mathbf{n = 8 2})\end{array}$ & $\begin{array}{c}\text { Men } \\
(\mathbf{n = 9 0})\end{array}$ & $\mathbf{p}$ \\
\cline { 2 - 5 } QOLIE-31(mean, SD) & & & & \\
Overall score & $49.22 \pm 17.52$ & $45.76 \pm 19.37$ & $52.21 \pm 23.74$ & $\mathbf{0 . 0 5 4}$ \\
Seizure worry & $41.63 \pm 26.89$ & $37.74 \pm 28.60$ & $45.17 \pm 37.59$ & 0.227 \\
Overall QOL & $50.36 \pm 18.75$ & $47.35 \pm 23.18$ & $53.11 \pm 23.60$ & 0.109 \\
Emotional well-being & $51.11 \pm 19.70$ & $49.85 \pm 22.70$ & $52.26 \pm 26.49$ & 0.526 \\
Energy/fatigue & $45.82 \pm 20.50$ & $43.07 \pm 23.84$ & $48.17 \pm 27.18$ & 0.194 \\
Cognitive functioning & $48.40 \pm 21.33$ & $43.98 \pm 24.40$ & $52.29 \pm 28.26$ & $\mathbf{0 . 0 4 1}$ \\
Medication effects & $36.50 \pm 27.07$ & $36.99 \pm 34.37$ & $35.65 \pm 33.54$ & 0.795 \\
Social functioning & $54.80 \pm 23.22$ & $48.92 \pm 28.56$ & $58.87 \pm 28.90$ & $\mathbf{0 . 0 4 3}$ \\
BDI (mean, SD) & $19.89 \pm 10.84$ & $20.59 \pm 12.80$ & $19.24 \pm 14.32$ & 0.517 \\
BAI (mean, SD) & $22.87 \pm 13.18$ & $24.12 \pm 15.58$ & $21.73 \pm 17.37$ & 0.346 \\
\hline
\end{tabular}

QOLIE-31: Quality of Life in Epilepsy-31 Inventory (QOLIE-31), BDI: Beck Depression Inventory, BAI: Beck Anxiety Inventory, SD: standard deviation, İndependent sample t-test and Mann Whitney $\mathrm{U}$ test were respectively used for normally and non-normally distributed data. 


\section{Correlation analysis between QOLIE-31 scores and disease-related factors in female PWE}

BDI and BAI scores were positively, while most of the QOLIE-31 subscale scores except for emotional well-being and medication effects were negatively correlated with seizure frequency in the last year. Additionally, a negative correlation was found between age with social functions and medication effects, and disease duration with an overall score and social functions. BAI scores were positively correlated with age and disease duration. (Table 3)

Table 3. Correlations between QOLIE-31, BDI and BAI scores, and disease-related variables in female patients with epilepsy

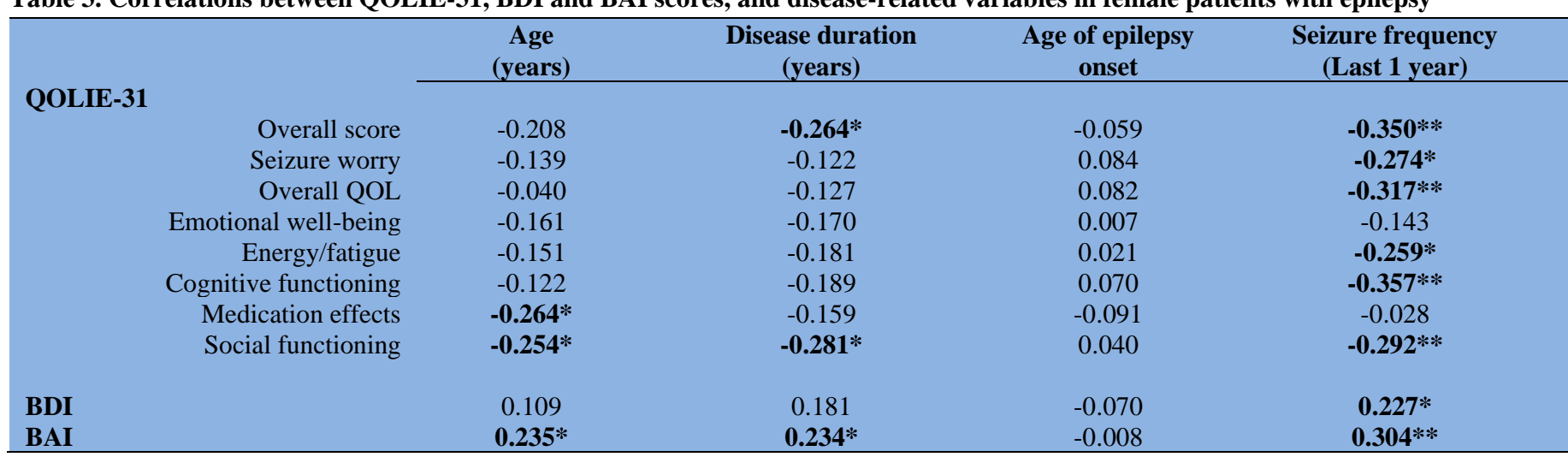

QOLIE-31: Quality of Life in Epilepsy-31 Inventory (QOLIE-31), BDI: Beck Depression Inventory, BAI: Beck Anxiety Inventory, SD: standard deviation. Pearson and Spearman correlation analysis were used. *Correlation is significant at the 0,05 level (2-tailed) ** Correlation is significant at the 0,01 level (2-tailed)

\section{Correlation analysis between QOLIE-31 scores and disease-related factors in male PWE}

The correlation analysis has showed that all of the QOLIE-31 subscales were negatively, BDI and BAI scores were positively correlated with seizure frequency in the last year (Table 4).

Table 4. Correlations between QOLIE-31, BDI and BAI scores and, disease-related variables in male patients with epilepsy

\begin{tabular}{|c|c|c|c|c|}
\hline & $\begin{array}{c}\text { Age } \\
\text { (years) }\end{array}$ & $\begin{array}{c}\begin{array}{c}\text { Disease duration } \\
\text { (years) }\end{array} \\
\end{array}$ & $\begin{array}{c}\text { Age of epilepsy } \\
\text { onset }\end{array}$ & $\begin{array}{c}\text { Seizure frequency } \\
\text { (Last } 1 \text { year) }\end{array}$ \\
\hline Overall score & -0.064 & -0.038 & -0.025 & $-0.489 * *$ \\
\hline Seizure worry & 0.120 & -00.10 & 0.108 & $-0.441 * *$ \\
\hline Overall QOL & -0.096 & -0.074 & -0.029 & $-0.470 * *$ \\
\hline Emotional well-being & -0.071 & -0.041 & -0.095 & $-0.452 * *$ \\
\hline Energy/fatigue & -0.044 & 0.004 & -0.041 & $-0.474 * *$ \\
\hline Cognitive functioning & -0.071 & -0.063 & -0.002 & $-0.383 * *$ \\
\hline Medication effects & 0.038 & -0.088 & -0.029 & $-0.536 * *$ \\
\hline Social functioning & 0.129 & -0.104 & -0.040 & $-0.381 * *$ \\
\hline BDI & 0.170 & 0.023 & 0.140 & $0.436 * *$ \\
\hline BAI & 0.017 & 0.000 & -0.033 & $0.386 * *$ \\
\hline
\end{tabular}

QOLIE-31: Quality of Life in Epilepsy-31 Inventory (QOLIE-31), BDI: Beck Depression Inventory, BAI: Beck Anxiety Inventory, SD: standard deviation. Pearson and Spearman correlation analyses were used. *Correlation is significant at the 0.05 level (2-tailed) ** Correlation is significant at the 0.01 level (2-tailed)

\section{Discussion}

Considering the bio-psycho-social aspects of life, gender differences may have a prominent role in all of the health issues. Consequently, men and women are affected by the same disease differently, therefore it is important to take into consideration these factors in the follow-up period of PWE. In this study, the QOL of men and women PWE was explored by using the QOLIE-31. Furthermore, we have evaluated separately the association between disease-related factors and QOL, depression, and anxiety symptoms in both genders.

The QOLIE-31 is a specific epilepsy inventory that examines prominent health-related QOL dimensions in people with epilepsy [10]. A systematic review from the USA has summarized 40 studies from 31 countries and reported the mean overall score of QOLIE-31 has been $59.8 \pm 8.0$, ranging from $48.7 \pm 10.8$ (Russia) to $70.8 \pm 13.3$ (Spain). In addition, two Korean studies by Choi et al. and Lee et al. has reported lower overall scores of QOLIE-31 (47.8 \pm 11.9 vs. $48.8 \pm 8.9$, respectively) in both gender which is consistent with our results $(49.22 \pm 17.52)[16,17]$. The reason for lower overall QOL scores in epilepsy may be related to participation from a tertiary care hospital where more severe patients are usually admitted, and/or living in a competitive and industrialized environment.

In our study, mean overall scores of QOLIE-31 are significantly lower in women than in men PWE (45.76 $\pm 19.37 \mathrm{vs} 52.21 \pm 23.74, \mathrm{p}=0.054)$. Moreover, women patients perform lower scores on cognitive functions ( $52.29 \pm 28.26 \mathrm{vs} 43.98 \pm 24.40, \mathrm{p}=0.041)$, and social functioning (58.87 \pm 28.90 vs $48.92 \pm 28.56, \mathrm{p}=0.043$ ) subscales of QOLIE-31.

Previous studies which were conducted in ethnic populations reported lower QOLIE-31 overall scores of women with epilepsy, while others did not find any gender differences between QOLIE-31 total scores in PWE [16-19]. A cross-sectional study which is conducted in Mexico has 
confirmed the fact that being female, having sleep disorders, lower socioeconomic status, and frequent seizures have a predictive role on poorer QOL (as measured by QOLIE-31) [18]. In addition, a cross-sectional, correlational study in Taiwan has reported significantly lower QOLIE-31 scores in female participants with epilepsy $(61.57 \pm 17.9$, vs $65.94 \pm 15.2, \mathrm{p}=0.03)$, and determined the positive predictive role of being male on health-related QOL (adj. $\left.R^{2}=0.007, \beta=0.09, p<0.05\right)$ Similar to our results, they have reported lower scores on cognitive functioning dimension of QOLIE-31 in female group $(56.08 \pm 22.6$, vs $64.84 \pm 19.6, \mathrm{p}<0.01)$ [19]. Furthermore, Lee et al. emphasized the significant association between the scores of the Social Support Scale and QOLIE-31 in female PWE. [17]. These findings suggest that female predominance in decreasing QOL in epilepsy may be related to the cultural discrepancy, hormonal alterations, lack of social support, and low self-esteem. For this reason, it is important to bear in mind that social and psychological support in the course of epilepsy have a beneficial role on health-related QOL, especially in women.

In the present study, most of the QOLIE-31 subscale scores of women except for emotional well-being and medication effects were associated with seizure frequency. All of the QOLIE-31 scores of the male group were significantly correlated with increased seizure frequency. In a crosssectional study from a tertiary care center in India has revealed a significant association between frequent seizures and poorer QOL in PWE [20]. Similarly, Dourado et al. has supported the predictive role of increased seizure frequency on decreasing health-related QOL in patients with temporal lobe, extratemporal lobe, and idiopathic generalized epilepsy [21]. In our study, the QOLIE-31 scores of social functioning were associated with age and longer disease duration, while the scores of medication effects were significantly correlated with age in women patients with epilepsy.

Previous studies have emphasized the prominent role of frequent seizures, longer disease duration, and effects of AEDs on decreasing QOL by using QOLIE-31 in PWE without the comparison of gender differences [22-24]. However, Bala et al. has revealed the fact that depression intensity has a predictive role on the scores of QOLIE-31 in male patients with drug-resistant epilepsy [25]. Similarly, Lee et al. reported a negative association between frequent seizures, daily-life stress, and anxiety with the scores of QOLIE-31 in male PWE [17]. Therefore, further research will be needed to explore predictive and associated factors on QOL in either women or men with epilepsy.

In general, women are more susceptible to depression and anxiety compared to men. [26, 27]. Nevertheless, we detected no significant changes in depression and anxiety scores between the groups, which is consistent with previous research on gender differences in PWE [28, 29]. In addition, depression and anxiety symptoms were associated with frequent seizures in male and female PWE. Also, higher anxiety levels were associated with older age and longer disease duration in women PWE.

\section{Limitations}

This study has several limitations. First, our study was conducted in a single tertiary care hospital which might be distinct from population-based samples that possibly cause sampling bias. Second, the study design was retrospective, cross-sectional with relatively small sample size. Third, depression and anxiety symptoms were assessed by patient's self-reported inventories without confirmation by the psychiatry consultation.

Additionally, all the valid and reliable inventories are the subjective tools to reflect QOL, depression, and anxiety in this study. However, to the best of our knowledge, this is the first report from our country that evaluates gender discrepancy on health-related QOL in people with epilepsy because we included patients with active epilepsy to compare the participants with similar disease-related problems in the clinical process. Therefore, this study has provided a different perspective about gender discrepancy regarding QOL in PWE.

\section{Conclusion}

In summary, our study suggests that women with epilepsy have had a decline in social and cognitive categories of the QOLIE-31 test. Moreover, seizure frequency is the most prominent disease-related factor associated with QOL, depression, and anxiety in both genders. Further studies about gender-specific approaches may improve management strategies and QOL in patients with epilepsy.

\section{Conflict of interest: None.}

\begin{tabular}{|l|l|}
\hline \multicolumn{1}{|c|}{ Author Contributions } & Author Initials \\
\hline Study Conception and Design (SCD) & SB \\
\hline Acquisition of Data (AD) & SB \\
\hline Analysis and Interpretation of Data (AID) & SB \\
\hline Drafting of Manuscript (DM) & SB \\
\hline Critical Revision (CR) & SB \\
\hline
\end{tabular}

\section{Financial support: None}

Acknowledgements: The author thanks to all patients who participated in this study.

Prior publication: This study was not presented in any meeting/congress, and not published in any journal.

\section{References}

1. Beydoun A, DuPont S, Zhou D, Matta M, Nagire V, Lagae L. Current role of carbamazepine and oxcarbazepine in the management of epilepsy. Seizure. 2020;83:251-63 https://doi.org/10.1016/j.seizure.2020.10.018. 
2. Thurman DJ, Beghi E, Begley CE, Berg AT, Buchhalter JR, Ding D, et al. ILAE commission on epidemiology: standards for epidemiologic studies and surveillance of epilepsy. Epilepsia. 201;52(7):2-26 https://doi.org/10.1111/j.1528-1167.2011.03121.x.

3. Taylor RS, Sander JW, Taylor RJ, Baker G, Predictors of health-related quality of life and costs in adults with epilepsy: a systematic review. Epilepsia 2011;52(12):2168-80 https://doi.org/10.1111/j.1528-1167.2011.03213.x.

4. Schachter SC. Improving quality of life beyond seizure control. Epileptic Disord. 2008;10(2):191.

5. Birbeck GL, Hays RD, Cui X, Vickrey BG. Seizure reduction and quality of life improvements in people with epilepsy. Epilepsia. 2002;43(5):535-8 https://doi.org/10.1046/j.1528-1157.2002.32201.x.

6. Basaran S, Tas Hİ. Predictive factors of quality of life in temporal and extratemporal lobe epilepsy: association with affective temperament profiles and psychiatric comorbidities. Arq Neuropsiquiatr. 2021;79(9):799-807 https://doi.org/10.1590/0004-282X-ANP-2020-0437

7. Yue L, Yu PM, Zhao DH, Wu DY, Zhu GX, Wu XY, et al. Determinants of quality of life in people with epilepsy and their gender differences. Epilepsy Behav 2011;22(4):692-6 https://doi.org/10.1016/j.yebeh.2011.08.022.

8. Devinsky O, Vickrey BG, Cramer J, Perrine K, Hermann B, Meador K, et al. Development of the quality of life in epilepsy inventory. Epilepsia. 1995;36(11):1089-104 https://doi.org/10.1111/j.1528-1157.1995.

9. Fisher RS, Acevedo C, Arzimanoglou A, Bogacz A, Cross JH, Elger CE, et al. ILAE official report: a practical clinical definition of epilepsy. Epilepsia. 2014;55(4):475-82 https://doi.org/10.1111/epi.12550.

10. Mollaoglu M, Durna Z, Bolayir E. Validity and reliability of the quality of life in epilepsy inventory (QOLIE-31) for Turkey. Noro Psikiyatr Ars. 2015;52(3):289-95 https://doi.org/10.5152/npa.2015.8727.

11. Beck AT, Ward CH, Mendelson M, Mock J,Erbaugh J. An inventory for measuring depression. Arch. Gen. Psychiatry. 1961;4(6):561-71 https://doi.org/10.1001/archpsyc.1961.01710120031004.

12. Hisli N. [The validity and reliability of the Beck depression inventory among university students] (in Turkish) Turk J Psychology 1989;7:313

13. Beck AT, Brown G, Epstein N, Steer RA. An inventory for measuring clinical anxiety - psychometric properties. J Consult Clin Psychol 1988;56:893-7.

14. Ulusoy M, Sahin NH, Erkmen H. Turkish version of the beck anxiety inventory: psychometric properties. J Cogn Psychother 1998;12:16372

15. Saadi A, Patenaude B, Mateen FJ. Quality of life in epilepsy-31 inventory (QOLIE-31) scores: A global comparison. Epilepsy Behav 2016; 65:13-7 https://doi.org/10.1016/i.yebeh.2016.09.032.

16. Choi-Kwon S, Chung C, Kim H, Lee S, Yoon S, Kho H, et al. Factors affecting the quality of life in patients with epilepsy in Seoul, South Korea. Acta Neurol Scand 2003;108(6):428-34 https://doi.org/10.1046/j.1600-0404.2003.00151.x.

17. Lee SA, Kim SJ, Han NE, Lee SM, No YJ. Gender differences in factors associated with resilience for health-related quality of life in persons with epilepsy. Epilepsy Behav. 2021;11(5):107-10 https://doi.org/10.1016/j.yebeh.2020.107710.

18. Alanis-Guevara I, Peña E, Corona T, López-Ayala T, López-Meza E, López-Gómez M. Sleep disturbances, socioeconomic status, and seizure control as main predictors of quality of life in epilepsy. Epilepsy Behav 2005;7(3):481-5 https://doi.org/10.1016/j.yebeh.2005.06.010.

19. Chen HF, Tsai YF, Hsi MS, Chen JC. Factors affecting quality of life in adults with epilepsy in Taiwan: A cross-sectional, correlational study. Epilepsy Behav 2016;58:26-32 https://doi.org/10.1016/i.yebeh.2016.02.019.

20. Thomas SV, Koshy S, Nair CR, Sarma SP. Frequent seizures and polytherapy can impair quality of life in persons with epilepsy. Neurol India. 2005;53(1):46-50 https://doi.org/10.4103/0028-3886.15054.

21. Dourado M, Alonso N, Martins H, Oliveira C, Vancini R, Lima C, et al. Quality of life and the self-perception impact of epilepsy in three different epilepsy types. J. epilepsy clin. neurophysiol. 2007;13(4):191-6 https://doi.org/10.1590/S167626492007000400009.

22. Guekht AB, Mitrokhina TV, Lebedeva AV, Dzugaeva FK, Milchakova LE, Lokshina OB, et al. Factors influencing on quality of life in people with epilepsy. Seizure. 2007;16(2):128-33 https://doi.org/10.1016/j.seizure.2006.10.011.

23. Melikyan E, Guekht A, Milchakova L, Lebedeva A, Bondareva I, Gusev E. Health-related quality of life in Russian adults with epilepsy: the effect of socio-demographic and clinical factors. Epilepsy Behav. 2012;25(4):670-5 https://doi.org/10.1016/j.yebeh.2012.09.042.

24. Piperidou C, Karlovasitou A, Triantafyllou N, Dimitrakoudi E, Terzoudi A, Mavraki E, et al. Association of demographic, clinical and treatment variables with quality of life of patients with epilepsy in Greece. Qual Life Res. 2008; 17(7):987-96 https://doi.org/10.1007/s11136008-9375-9.

25. Bala A, Szantroch M, Gleinert A, Rysz A, Marchel A. Differences in quality of life of women and men with drug-resistant epilepsy in Poland. Epilepsy Behav. 2016;60:94-98 https://doi.org/10.1016/j.yebeh.2016.04.041.

26. Albert PR. Why is depression more prevalent in women? J Psychiatry Neurosci. 2015;40(4):219-21 https://doi.org/10.1503/jpn.150205.

27. McLean CP, Asnaani A, Litz BT, Hofmann SG. Gender differences in anxiety disorders: prevalence, course of illness, comorbidity and burden of illness. J Psychiatr Res. 2011;45(8):1027-35 https://doi.org/10.1016/j.jpsychires.2011.03.006.

28. Gaus V, Kiep H, Holtkamp M, Burkert S, Kendel F. Gender differences in depression, but not in anxiety in people with epilepsy. Seizure (2015)32:37- 42 https://doi.org/10.1016/j.seizure.2015.07.012.

29. Liu Z, Yin R, Fan Z, Fan H, Wu H, Shen B, et al. Gender differences in associated and predictive factors of anxiety and depression in people with epilepsy. Front Psychiatry. 2020;10 (11): 670 https://doi.org/10.3389/fpsyt.2020.00670 